UDC 811.161.1'243: 378

DOI https://doi.org/10.32838/2663-6069/2020.3-3/38

Chen Shaoxiong

Huzhou University (China)

\title{
FORMATION OF RUSSIAN-LANGUAGE COMMUNICATIVE COMPETENCIES IN STUDENTS STUDYING THE HUMANITIES
}

Language (speech) competence is an integral part of the communicative competence, and the communicative competence is included in the general set of socionic competencies as obligatory. Based on the foregoing, it can be argued that the realized language discourse is the essence of the process of professional activity. This activity is aimed at transforming the social environment or managing the social environment (competence as performance). The basic tool in this case is knowledge of language units and their functions.

The article deals with the application of the structural communicative method in the initial study of the subject "Russian Language in Professional Communication". The study proved the reasonability of changing the educational conditions (content) of the first module in order to improve literacy and communication indicators (markers) in professional communication. In this case, the hypothesis of this scientific work is the thesis that the transformation of the above conditions using a structural communicative approach will increase objective indicators of speech literacy. The objective of the study is the formulation, development and experimental verification of new educational conditions for teaching and studying the Russian language as a language of professional communication. The results of studying the Russian language as a language of professional communication in the control and experimental groups are compared. The local effectiveness of experimental restructuring of the content using the structural communicative approach is proved. The study used the method of structuring didactic material, modelling didactic conditions, predicting their results; diagnostic methods (observation, interview, testing), as well as a method of comparing the results of educational activities of the experimental and control groups. The scope of methodological developments and the data obtained as a result of the experiment covers a cycle of the humanities with the study of Russian as a language of the professional sphere. The results of the study can serve as a basis for updating curricula, programmes and methodological tools in teaching Russian as a foreign language and as a language of professional communication for students of the People's Republic of China and other countries.

Key words: competencies, socionic professions, structural approach, content module, literacy indicators, curriculum.

Introduction. Among the broadest general cultural competencies of bachelors of a socionomic specialization is the willingness to communicate in a multicultural environment. This is especially important in bilingual or multilingual sociocultural space. In this regard, an important methodological objective is the formation of speech and, more broadly, communicative competencies in the study of a foreign language. The Russian language, which is the sixth most widely spread language in the world, deserves special attention, since it is studied at many world leading universities as a foreign language. Atthesame time, the prevailing number of methodological studies deals with the English language as an unofficially main language of international communication. Based on considerations of tolerance and support for a multicultural environment in the Eurasian region, the problem of teaching the Russian language in higher educational institutions of China is especially important. First of all, this concerns the training of personnel of a socionomic specialization, since the humanitarization of society and the interpenetration of forms of its public consciousness are key trends of the present and near future.

This article intends to reveal the potential of astructural communicativeapproachinthe formation of Russian- language competence. To this end, the prevailing pedagogical principles in Western European countries and the People's Republic of China were investigated, changes in the content structure of the subject "Russian Language in Professional Communication" on the basis of Huzhou University were modelled and experimentally verified.

The scientific hypothesis of the study is the thesis that the improvement of the structural communicative 
approach and its use at the initial stages of studying the Russian language as a professional by Chinese students will increase communicative competencies in general.

Recently, little attention has, however, been paid in methodological literature to the structural principle of language learning, although this method is widely used in national traditions of teaching foreign languages (countries of the former Commonwealth of Independent States, Eastern Europe and Asia). This article aims to reasonably combine communicative and structural methods in the formation of Russianlanguage communicative competencies in students studying the humanities at Huzhou University.

Literature review. Features of the methodology of teaching foreign languages have repeatedly become the subject of study of modern scholars from different countries. Teaching foreign languages (mainly English) in Asian countries is based on multimedia technologies in linguodidactics $[22 ; 9 ; 12]$. German methodologists $[6 ; 10 ; 18 ; 20 ; 21]$ provide general practical recommendations for the study of foreign languages are given in their works. The largest number of works on communicative principles are written in English and describe the experience of teaching English in the context of the specifics of different countries $[19 ; 8 ; 1 ; 2 ; 16 ; 17$ and others].

The theoretical basis of this study is the concepts of modern linguodidactic methodologists. German scholars believe that the subject of linguistic and communicative competencies lies in the field of developmental psychology and psycholinguistics and has different perspectives. The structure of linguistic competence is multilevel, but it is possible to distinguish the linguistic substructure of skills in it [6].

In modern German-language scientific discourse, a controversial assumption regarding the structural approach is also methodologically justified. According to it, oral speech competencies are more important than theoretical knowledge of vocabulary and grammar. The latter are "layered" on basic speech skills. Moreover, the first language learned (die erste Sprache) acts as the basis for the internalization of the second, foreign language (die Fremdsprache) [20]. In connection with the above provisions, it was decided to use a limited structural approach when modelling new pedagogical situations.

In English-language methodological sources, there are tendencies towards a culturally and communicatively oriented study of foreign languages (mainly English) [8]; integrated learning based on popular content [16]; study based on the latest digital and multimedia technologies [4]. Moreover, there are virtually no studies of the teaching methods of the Russian language at universities, which adds to the topicality of our study.

The structural approach is typical mainly for Russian linguodidactics when teaching foreign students or when learning Russian as a second language in bilingual conditions. In this approach, phonological, lexical, grammatical and spelling competencies were structurally distinguished and argued. We used this structure in the formation of the content of the experimental programme of the first module (see Table 1).

Methods and materials. The research material was the experimental programme "Russian Language in Professional Speech" developed by the author for the School of Humanities of Huzhou University (PRC), as well as the statistical results of the implementation of the aforementioned program $[11 ; 15]$. At the propaedeutic stage, we used the method of structuring the language material and setting the correlation relations of the language units with the pragmatic and communicative component (Table 5). At the implementation stage, we used the methods of modelling the educational process and predicting the effectiveness of the subject "Russian Language in Professional Communication" $[5 ; 2]$ and experimental methods: observation of the educational process, testing and interviewing with participants in the control and experimental groups [7]. The final method was the comparative one (comparing changes in basic knowledge and literacy of the control and experimental groups (see Figure 2). Diagnostics of the results of the experimental and standard development of language competencies was carried out by testing and oral interviews, followed by an average value on a 10-point scale in accordance with modern statistical methods [3; 13].

Results. Using H. Yude's thesis on the structure of linguistic competencies [6], as well as our own experience, we created a structural pyramid of linguistic competencies, which is based on linguistic skills (see Figure 1).

Such a schematic system of an hierarchy of linguistic competencies, which is based on basic structural cognitive education, contributed to the choice of a structural communicative approach in building the first substantive module of the analyzed subject.

As we can see from the schematic (and hierarchical) image of the structure of linguistic competencies, they are based on knowledge and possession of linguistic units (phonetic, morphemic, lexical and grammatical). 
During the implementation of the experimental (pilot) training course "Russian Language in Professional Communication", the following methodological changes were introduced in the didactic process:

1. The linguistic component of the course content (structural communication approach) in the first semester of the subject study was expanded.

2. The structural and functional study of linguistic units was implemented only within the first content module. Communicative competencies only were developed later.

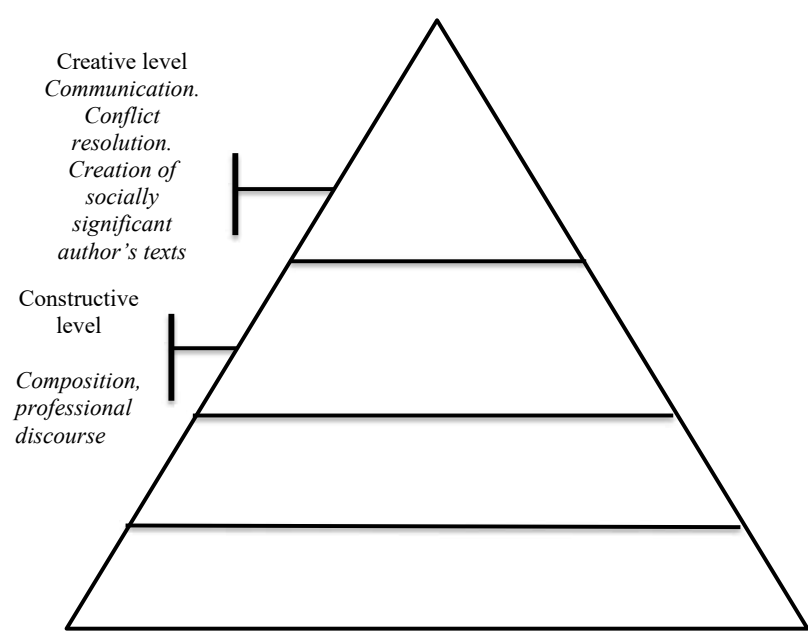

Fig. 1. Hierarchy of linguistic competencies

3. All linguistic aspects were taught based on the principle of "repeating basic knowledge deepening - functioning in the professional discourse of the humanities".

4. The main applied principle of the structural study of linguistic units consisted in the attitude "linguistic unit - its functionality - application in professional discourse".

As part of the first content module, it is proposed to implement a structural approach as a basis for the development of stylistic and communicative competencies. To do this, the study of the hierarchy of non-independent language units in the binary correlation "unit - its functionality" was included in the teaching materials. As part of the experiment, a restructuring of the first content module of the subject "Russian Language in Professional Communication" was proposed according to the following scheme:

Confirmation of the local effectiveness of the didactic innovations proposed above is the result of comparing the oral and written literacy of the experimental and control groups (see Figure 2).

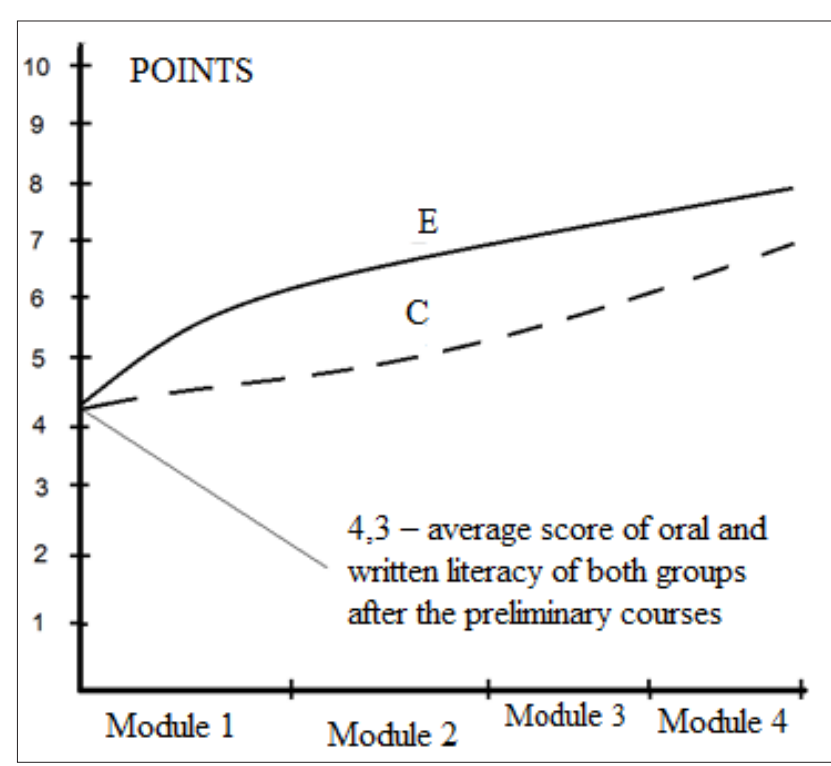

Fig. 2. Graphic representation of the dynamics of literacy indicators in the experimental and control groups

The graph demonstrates the local effectiveness of the structural communicative approach to didactic content and implementation of the first module of the subject "Russian Language in Professional Communication". The initial level of language proficiency is below average (4.3 points after preliminary courses). Students of the experimental group showed an increase in literacy markers (solid curve) compared to the control group (dashed curve).

Discussion. The study of relevant literature on the development of Russian-language competencies in

Table 1

Structuring the experimental content module

\begin{tabular}{|c|c|}
\hline Structural component & Communicative and spelling (orthoepic) component \\
\hline $\begin{array}{l}\text { Phonetic system } \\
\text { Phonological system } \\
\text { Lexico-phraseological system } \\
\text { Word-formation and morpheme } \\
\text { systems } \\
\text { Morphological system } \\
\text { Syntactical system }\end{array}$ & $\begin{array}{l}\text { Pronunciation of vowels and consonants. Unstressed vowels, alternating } \\
\text { vowels and consonants. Phonetic aspects of spelling. The semantic function } \\
\text { of phonemes. Stress. Intonation of sentences by the purpose of the statement. } \\
\text { Active dictionary. Phraseological richness of the Russian language. Basic } \\
\text { deontological terms and turns. } \\
\text { Productive suffixes and prefixes. Morphological alternations of phonemes. The } \\
\text { main types of word formation. The morphological principle of spelling } \\
\text { Types of sentences. Composite sentences in professional speech. Punctuation. }\end{array}$ \\
\hline
\end{tabular}


Asian countries indicates the penetration of European trends into their methodological paradigm. For example, two types of competencies are relevant at the Department of the Russian Language of the University of Baghdad: "general (knowledge about the world, national and universal cultures, skills, learning ability, individual life experience) and communicative linguistic, consisting of three components - linguistic, sociolinguistic and pragmatic" [16]. As we can see, recently researchers consider it necessary to introduce a structural component against the background of the socio-cultural component of education, since the difference in rendering lexical and grammatical phenomena in Russian and a number of Asian languages (Chinese, Iranian) is significant. Inflectional ways of expressing grammatical meanings are almost not used in the Persian language, agglutination is observed. Chinese languages are characterized by agglutination of root and suffix meanings with the prevalence of two-part words.

The application of elements of a structural approach will help to understand the internal philosophy of the language with the inflective-synthetic nature of grammar. An important principle in this case should remain the correlation between the structure of the literary language and communication, multimedia and mass media content. The latter are much closer to linguistic pragmatics than literary language.

"Performance methods" come first among alternative methods of teaching foreign languages in modern China. They suggest the formation of initial language competencies through the perception of textual or oral speech discourses. For example, since 2016 in China, the executive branch (administration) has legally encouraged the study of English and/

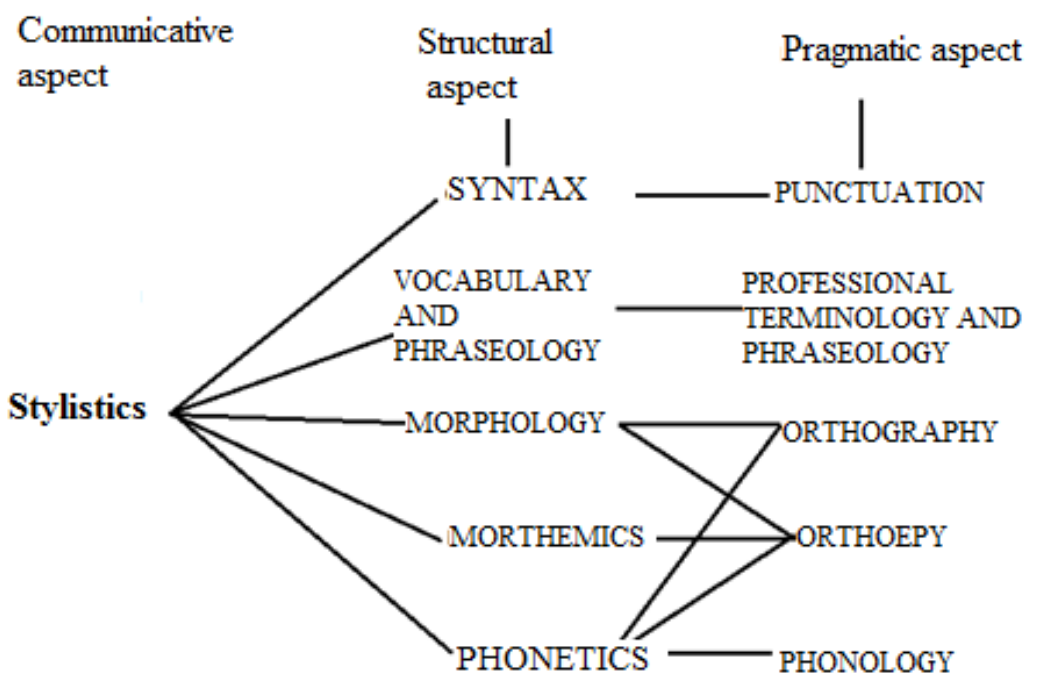

Fig. 3. Correlation of structural levels of the Russian language with the pragmatics of its use or Russian using synthetic forms of art, such as drama. This approach helps to develop creativity, solve conflict situations, develops communication and empathy, a positive attitude and self-confidence [8]. In our model, subsequent content modules (except the first) are built according to the communicative principle and also contain work with artistic discourse.

German experts believe that language competencies differ depending on the initial degree of language proficiency. In this regard, we can distinguish institutional ties between linguistic competencies within native (in der Erstsprache) or foreign (in der Fremdsprache) languages. A separate study model should be applied in a bilingual environment. So, according to the aforementioned concept, three types of language spaces can be distinguished and, accordingly, three approaches to the study of Russian in the professional sphere: Russian as a native language (Russia), Russian as a second language in a bilingual society (republics of the former CIS, diaspora) and Russian as a foreign language (in our case - in the People's Republic of China).

In this study, a structural communicative model is presented and tested. Moreover, as a postulate, a concept has been adopted related to the humanization and informatization of the educational process in most countries. The nature of this postulate is that in the humanities, interpenetration is observed and linguistic competence is no longer autonomous. It is mandatory and service competence within the main socionic competencies (legal, pedagogical, psychological, etc.).

Until recently, the structural approach prevailed when developing curricula and syllabuses on the subject "Russian Language in Professional Communication". It involved the gradual development oflinguistic levels (phonetic, word-building, lexical, grammatical, stylistic). At the same time, correlation relations were established at each level directly with professional speech, for example: "Noun and legal terminology"; "Word building and its stylistic potential"; "Phraseology of the Russian language and professional clichés in business", etc. The weakness of this (structural) approach is often the formal relationship between the language unit (level) and the communicative component, therefore the structural approach is applied in the experiment only in the first module, and in correlation with language functions (see Figure 3). 
Thus, the discussion of the key provisions of this article with the leading linguodidactic principles allows the appropriate application of the structural approach within the structural communicative (author's term) as a more universal one.

Conclusions. Linguistic (speech) competence is an integral part of the communicative competence, and communicative competence is included in the general set of socionic competencies as obligatory. Based on the foregoing, it can be argued that the implemented language discourse is the process of professional activity. Such activities are aimed at transforming the social environment or managing the social environment (competence as performance). An elementary tool in this case is knowledge of the language units and their functions.

The problem of communicative competencies of future journalists, lawyers, psychologists requires the maximum universalization of the study of the structural foundations of the Russian language as heteromorphic in comparison with Chinese languages. Socionic activity of a professional involves the development of intersocial (perceptual, social, verbal,psychological, creative)competencies. This is the basis of successful professional activity, therefore the formation of individual competencies is not a valid and sufficient result of study. But the application of a structural approach to the study of stylistic and communicative functions of individual language units is advisable in the first stages of teaching the subject"Russian Language in Professional Communication". This is evidenced by the statistics shown in Figure 2: initial result 4.3 points; the final result is 7.8 points (average in the experimental group), 6.9 in the control group).

The results of the work can be applied in the development of Russian-language courses for foreign students, in the study of Russian as a foreign language. They can also serve as a starting point for further linguodidactic research using a structural and communicative teaching method.

\section{References:}

1. Ackerley K. Effects of corpus-based instruction on phraseology in learner English. Language Learning \& Technology. 2017. No. 21 (3). P. 195-216. URL: http://llt.msu.edu/issues/october2017/ackerley.pdf.

2. Bezukladnlkov K. E., Shamov A. N. and Novoselov M. N. Modeling of Educational Process Aimed at Forming Foreign Language Professional Lexical Competence. World Applied Sciences Journal. 2013. No. 22 (7). P. 903-910.

3. Bhatia M. A Complete Guide to Quantitative Research Methods. Humans of Data. 2018. URL: https://humansofdata.atlan.com/2018/06/quantitative-research-methods/ (Last accessed: 17.03.2020).

4. Dubiner D. Second language learning and teaching: From theory to a practical checklist. Wiley. 2018. URL: https://onlinelibrary.wiley.com/doi/abs/10.1002/tesj.398 (Last accessed: 17.03.2020).

5. Goldstein H. Methods in school effectiveness. Research. School Effectiveness and School Improvement. 1997. No. 8. P. 369-395.

6. Jude N. Zur Struktur von Sprachkompetenz. Dissertion, Universität Frankfurt. 2008. URL: http://publikationen.ub.uni-frankfurt.de/files/6694/Jude_Zur_Struktur_... (Last accessed: 17.03.2020).

7. Green A. Exploring Language Assessment and Testing: Language in Action New York : Routledge. 2013. P. 288.

8. Kavakli N. A gimmick for mimmick: the ELF student-teachers' attitudes towards drama course. International Online Journal of Education and Teaching. 2016. No. 3 (2). P. 122-130.

9. Lin C. Research on Core Competence of Student Development in the 21st Century. Beijing Normal University Press : Beijing. 2016.

10. Krelle M., Spiegel C. Sprechen und Kommunizieren: Entwicklungsperspektiven, Diagnosemöglichkeiten und Lernszenarien in Deutschunterricht und Deutschdidaktik. Schneider Verlag Hohengehren, 2009. 300 p.

11. Pagani L., Chiara S. A statistical analysis of teaching effectiveness from students' point of view. Developments in statistics. 2002. No. 17. P. 197-208.

12. Lin Y. J., Wang H. C. Using enhanced OER videos to facilitate English L2 learners' multicultural competence. Computer Assisted Language Learning. 2018. Vol. 31. P. 5-6.

13. Luby S., Southern D. The Pathway to Publishing: A Guide to Quantitative Writing in the Health Sciences. 2017. URL: http://globalhealth.stanford.edu/wp-content/uploads/2019/07/A-Guide-to-Quantitative-ScientificWriting-V-23.pdf (Last accessed: 17.03.2020).

14. Menghan Z., Tao G. Principles of parametric estimation in modeling language competition PNAS. 2013. Vol. 110 (24). P. 9698-9703. URL: https://doi.org/10.1073/pnas.1303108110 (Last accessed: 17.03.2020).

15. McCauley S. M., Christiansen M. H. Learning Simple Statistics for Language Comprehension and Production: The CAPPUCCINO Model. Proceedings of the Annual Meeting of the Cognitive Science Society. 2013. Vol. 33. URL: https://escholarship.org/uc/item/97g4d9pc (Last accessed: 17.03.2020). 
16. Pavón V., López J. Á., Gallego A. S. \& Espejo R. M. Strategic and organizational considerations in planning content and language integrated learning: a study on the coordination between content and language teachers. International Journal of Bilingual Education and Bilingualism. 2014. DOI: https://doi.org/10.1080/13670050.20 14.909774.

17. Bygate M., Skehan P., Swain M. (2013). Researching pedagogic tasks: Second language learning, teaching, and testing. Harlow, UK : Pearson Education. 258 p.

18. Rösler D. Deutsch als Fremdsprache. Sammlung Metzler Realien zur Sprache. Weimar : Verlag J. B. Metzler Stuttgart, 1994. $222 \mathrm{p}$.

19. Tomlinson B. The Importance of Materials Development for Language Learning. Issues in Materials Development. Critical New Literacies: The Praxis of English Language Teaching and Learning (PELT). Sense Publishers, Rotterdam. 2016. URL: https://brill.com/view/book/edcoll/9789463004329/BP000002.xml (Last accessed: 17.03.2020).

20. Vaittinen R. Die mündliche Sprachkompetenz in den Sprechübungen des Lehrwerkes Magazin.de. 2017. URL: https://jyx.jyu.fi/bitstream/handle/123456789/53502/1/URN\%3ANBN\%3Afi\%3Ajyu-201704051911.pdf (Last accessed: 17.03.2020).

21. Van Compernolle, Rémi A. Interaction and Second Language Development: A Vygotskian perspective. Amsterdam / Philadelphia : John Benjamins B. V., 2015. 226 p.

22. Yamazaki K. Computer-assisted learning of communication (CALC): A case study of Japanese learning in a 3D virtual world 4. Vol. 30. Special Issue 2 (Interactions for language learning in and around virtual worlds). 2018. P. 214-223. URL: https://www.cambridge.org/core/journals/recall/article/computerassisted-learning-ofcommunication-calc-a-case-study-of-japanese-learning-in-a-3d-virtual-world/3B555ED898D013AC5F02FEAA 7EE462EE (Last accessed: 17.03.2020).

\section{Чень ШаосюН. ФОРМУВАННЯ РОСІЙСЬКОМОВНИХ КОМУНІКАТИВНИХ КОМПЕТЕНТНОСТЕЙ У СТУДЕНТІВ ГУМАНІТАРНОГО ПРОФІЛЮ}

Стаття присвячена застосуванню структурно-комунікативного методу під час початкового вивчення навчальної дисиипліни «Російська мова в професійному спілкуванні». У дослідженні доведено доцільність зміни освітніх умов (змістовного наповнення) першого модуля з метою поліпшення грамотності та комунікативних показників (маркерів) у професійному спілкуванні. Водночас гіпотезою иієї наукової роботи виступає теза про те, щьо трансформація вищезазначених умов за допомогою сттруктурно-комунікативного підходу підвищить об'єктивні показники мовної грамотності. Завданням дослідження $\epsilon$ формулювання, розроблення та експериментальна перевірка нових освітніх умов викладання та вивчення російської мови як мови професійного спілкування. Водночас зіставлено результати вивчення російської мови як мови професійного спілкування в контрольних і експериментальних групах. Доведено локальну ефективність експериментальних реструктуризацій змістовного аспекту з використанням структурно-комунікативного підходу. У дослідженні застосовувався метод структурування дидактичного матеріалу, моделювання дидактичних умов, прогнозування їхніх результатів; діагностичні методи (спостереження, співбесіда, тестування), а також метод порівняння результатів навчальної діяльності експериментальної $і$ контрольної груп. Сфера застосування методичних розробок і отриманих у результаті експерименту даних охоплює цикл гуманітарних спеціальностей із вивченням російської мови як мови професійної сфери. Результати дослідження можуть послужити базою для поновлення навчальних планів, програм і методичного інструментарію у викладанні російської мови як іноземної $і$ як мови професійного спілкування для студентів Китайської Народної Республіки та інших краӥн.

Ключові слова: компетентності, соціонімічні професї̈, структурний підхід, змістовний модуль, показники грамотності, навчальна програма. 